University of Montana

ScholarWorks at University of Montana

Ecosystem and Conservation Sciences Faculty

Publications

Ecosystem and Conservation Sciences

$3-2014$

\title{
Assessing Nutrient Limitation in Complex Forested Ecosystems : Alternatives to Large-Scale Fertilization Experiments
}

\author{
Benjamin W. Sullivan \\ The University Of Montana, benjamin.sullivan@umontana.edu \\ Silvia Alvarez-Clare \\ The University of Montana, silvia.alvarez.clare@gmail.com \\ Sarah C. Castle \\ University of Montana - Missoula \\ Stephen Porder \\ Brown University, Providence, Rhode Island \\ Sasha C. Reed \\ U.S. Geological Survey, Canyonlands Research Station, Moab, Utah \\ See next page for additional authors \\ Follow this and additional works at: https://scholarworks.umt.edu/decs_pubs \\ Part of the Forest Sciences Commons \\ Let us know how access to this document benefits you.
}

\section{Recommended Citation}

Sullivan, Benjamin W.; Alvarez-Clare, Silvia; Castle, Sarah C.; Porder, Stephen; Reed, Sasha C.; Schreeg, Laura; Cleveland, Cory C.; and Townsend, Alan R., "Assessing Nutrient Limitation in Complex Forested Ecosystems : Alternatives to Large-Scale Fertilization Experiments" (2014). Ecosystem and Conservation Sciences Faculty Publications. 41.

https://scholarworks.umt.edu/decs_pubs/41

This Article is brought to you for free and open access by the Ecosystem and Conservation Sciences at ScholarWorks at University of Montana. It has been accepted for inclusion in Ecosystem and Conservation Sciences Faculty Publications by an authorized administrator of ScholarWorks at University of Montana. For more information, please contact scholarworks@mso.umt.edu. 


\section{Authors}

Benjamin W. Sullivan, Silvia Alvarez-Clare, Sarah C. Castle, Stephen Porder, Sasha C. Reed, Laura Schreeg, Cory C. Cleveland, and Alan R. Townsend 


\title{
Assessing nutrient limitation in complex forested ecosystems: alternatives to large-scale fertilization experiments
}

\author{
Benjamin W. Sullivan, ${ }^{1,4}$ Silvia Alvarez-Clare, ${ }^{1}$ Sarah C. Castle, ${ }^{1}$ Stephen Porder ${ }^{2}$ Sasha C. Reed, ${ }^{3,5}$ \\ Laura Schreeg, ${ }^{2}$ Alan R. Townsend, ${ }^{3}$ and Cory C. Cleveland ${ }^{1}$ \\ ${ }^{1}$ Department of Ecosystem and Conservation Sciences, University of Montana, 32 Campus Drive, Missoula, Montana 59812 USA \\ ${ }^{2}$ Department of Ecology and Evolutionary Biology, Brown University, Providence, Rhode Island 02912 USA \\ ${ }^{3}$ Department of Ecology and Evolutionary Biology, Environmental Studies Program, and Institute of Arctic and Alpine Research, \\ University of Colorado, Boulder, Colorado 80309 USA
}

\begin{abstract}
Quantifying nutrient limitation of primary productivity is a fundamental task of terrestrial ecosystem ecology, but in a high carbon dioxide environment it is even more critical that we understand potential nutrient constraints on plant growth. Ecologists often manipulate nutrients with fertilizer to assess nutrient limitation, yet for a variety of reasons, nutrient fertilization experiments are either impractical or incapable of resolving ecosystem responses to some global changes. The challenges of conducting large, in situ fertilization experiments are magnified in forests, especially the high-diversity forests common throughout the lowland tropics. A number of methods, including fertilization experiments, could be seen as tools in a toolbox that ecologists may use to attempt to assess nutrient limitation, but there has been no compilation or synthetic discussion of those methods in the literature. Here, we group these methods into one of three categories (indicators of soil nutrient supply, organismal indicators of nutrient limitation, and lab-based experiments and nutrient depletions), and discuss some of the strengths and limitations of each. Next, using a case study, we compare nutrient limitation assessed using these methods to results obtained using large-scale fertilizations across the Hawaiian Archipelago. We then explore the application of these methods in high-diversity tropical forests. In the end, we suggest that, although no single method is likely to predict nutrient limitation in all ecosystems and at all scales, by simultaneously utilizing a number of the methods we describe, investigators may begin to understand nutrient limitation in complex and diverse ecosystems such as tropical forests. In combination, these methods represent our best hope for understanding nutrient constraints on the global carbon cycle, especially in tropical forest ecosystems.
\end{abstract}

Key words: enzymes; foliar nutrients; Long Substrate Age Gradient; net primary productivity; nitrogen; phosphorus; resorption; root ingrowth cores; tropical forests.

\section{INTRODUCTION}

The limitation of plant growth by nutrients, such as nitrogen $(\mathrm{N})$ and phosphorus $(\mathrm{P})$, was first explored by crop and soil scientists who developed an operational definition of nutrient limitation that sought to maximize crop yield: if adding a nutrient increased crop yield, the crop was limited by that nutrient (Sprengel 1828 and

Manuscript received 2 May 2013; revised 22 July 2013; accepted 31 July 2013. Corresponding Editor: J. B. Yavitt.

${ }^{4}$ E-mail: benjamin.sullivan@umontana.edu

5 Present address: United States Geological Survey, Canyonlands Research Station, 2290 South West Resource Boulevard, Moab, Utah 84532 USA.
Liebig 1840, cited in van der Ploeg et al. 1999). Crop scientists have been largely successful at overcoming the constraints of nutrient limitation, chiefly through widespread manufacture and application of inorganic fertilizers (e.g., Tilman et al. 2002). However, as noted by Chapin et al. (1986), applying a simple, yield-centric lens to nutrient limitation in natural ecosystems overlooks many inherent complexities. For example, species within the same ecological community (or even individuals of different sizes among species) may differ in the extent and identity of nutrient limitation (e.g., Alvarez-Clare et al. 2013), the proximate limiting nutrient may change over multiple time scales (e.g., Harrington et al. 2001, Davidson et al. 2007), and 
different nutrients might limit different (but critical) ecosystem processes (e.g., Wright et al. 2011).

Despite these challenges, ecologists have used fertilization experiments for nearly as long as crop scientists have in agrarian ecosystems (Lawes and Gilbert 1880). Although more nuanced definitions for natural ecosystems have been developed (e.g., Chapin 1980, Chapin et al. 1986, Vitousek et al. 2010), the essence of these definitions remains operationally defined: if an added nutrient stimulates an ecosystem process that is the net result of the community assemblage of plant species (such as NPP), that process was limited by the nutrient (Vitousek and Howarth 1991). More recently, the definition of nutrient limitation has expanded to distinguish "proximate" nutrient limitation (an added nutrient that stimulates an ecosystem process) from "ultimate" nutrient limitation (a nutrient that fundamentally alters an ecosystem) (Vitousek et al. 2010). Still, the common denominator of most ecological definitions of nutrient limitation is a requirement for nutrient additions.

Theoretically, the ideal test of nutrient limitation (as defined by Chapin et al. 1986) would include comparing the relative growth rates of common species among fertilized and unfertilized sites that comprise a gradient of nutrient supply (e.g., Vitousek 2004). However, wellconstrained gradients of nutrient availability are rare (e.g., Peltzer et al. 2010). Thus, fertilization experiments remain widely viewed as the most robust method to assess nutrient limitation (e.g., Eviner et al. 2000, Elser et al. 2007, Cleveland et al. 2011), but the efficiency of fertilizer experiments is a function of turnover times of the community of interest. The relatively high abundance of aquatic studies may partly reflect the rapid turnover times of microbial communities in aquatic ecosystems (Fig. 1a) but it is important to recognize that there are other distinctions between nutrient limitation in aquatic and terrestrial ecosystems (reviewed in Grimm et al. 2003). Among terrestrial ecosystems, short statured plants in grassland, shrubland, and tundra ecosystems require modest plot sizes and provide growth responses and species composition shifts over relatively short timescales (Gough et al. 2000). As with aquatic studies, the utility of fertilizer experiments in shortstatured ecosystems is reflected by the abundance of studies performed in these regions relative to other terrestrial ecosystems (Fig. 1a; Elser et al. 2007). On the other hand, fertilization experiments in forests comprise only $\sim 4 \%$ of all in situ fertilization experiments globally to date (Elser et al. 2007, Harpole et al. 2011).

Forested ecosystems, and especially diverse lowland tropical forests, present a number of challenges for fertilization experiments (see Plate 1). For instance, long-term experiments carried out on large plots are often necessary to observe proximate nutrient limitation in forests (e.g., Harrington et al. 2001, Vitousek 2004). In a relatively low-diversity tropical ecosystem in Hawaii, Harrington et al. (2001) demonstrated that at least six years of fertilization indicated nutrient limitation consistent with nutrient supply along a nutrient availability gradient (Fig. 1b). Establishing ultimate limitation requires even more time: even in high-NPP forests of Panama, 11 years of fertilization were required before signs of community compositional shifts and growth responses became apparent (Wright et al. 2011), putting such experiments well beyond the time frame of typical funding cycles. Not surprisingly, there are a paucity of experimental data describing nutrient limitation in high-diversity, uneven-aged tropical forests: only three full-factorial $(\mathrm{N} \times \mathrm{P})$ fertilization experiments assessing NPP in diverse lowland tropical forests have been reported in the literature (Mirmanto et al. 1999, Wright et al. 2011, Alvarez-Clare et al. 2013). However, even long-term inorganic fertilizer experiments have some drawbacks. For example, inorganic fertilizer additions, which may be prone to losses, may be a less effective supply of nutrients to plants than are organic nutrient amendments (Sayer et al. 2012). Moreover, fertilization experiments are also unlikely to capture micronutrient limitation, especially on large spatial scales and when done in a full-factorial design with macronutrients, in part because commercial macronutrient fertilizer are often contaminated with micronutrients. For example, Barron et al. (2008) showed that molybdenum (Mo) limited leaf litter biological $\mathrm{N}$ fixation in lowland forests of Panama, leading the authors to suggest that Mo, commonly present as a contaminant in $\mathrm{P}$ fertilizer, may indirectly limit tropical ecosystem processes such as decomposition or NPP.

Thus, as a tool to understand global change scenarios, fertilization experiments clearly represent a two-edged sword. They provide results deeply grounded in the fundamental methods of agriculture and ecology, but in forested ecosystems they may not detect heterogeneous nutrient limitation, co-limitation, and ultimate nutrient limitation. For example, small trees may respond to fertilization differently than large trees (Fig. 1c), and different life history traits may lead to differences in nutrient requirements and fertilization responses among species (Wright et al. 2011, Alvarez-Clare et al. 2013, Fisher et al. 2013). Given the rapid pace of rising atmospheric $\mathrm{CO}_{2}$ concentrations and other global changes, however, ecologists lack the luxury of decades-long experiments to understand nutrient constraints on anthropogenic perturbations to ecosystems. In the case of predicting responses to rising $\mathrm{CO}_{2}$, there is an additional fundamental concern: fertilization experiments add nutrients to ecosystems, whereas elevated $\mathrm{CO}_{2}$ concentrations will make nutrients less abundant relative to $\mathrm{C}$ (e.g., Luo et al. 2006).

What other options exist? Fortunately, ecologists have at their disposal a number of methods beyond plot-scale fertilizations that may provide a more diverse "toolbox" to assess nutrient limitation. To date, there has been little discussion or synthesis of such alternatives. Here, we review a suite of methods used to assess 
a

Fertilization experiments in the world's biomes

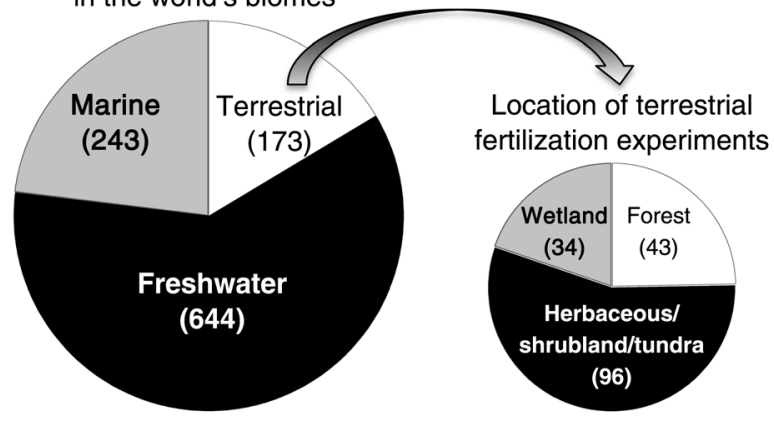

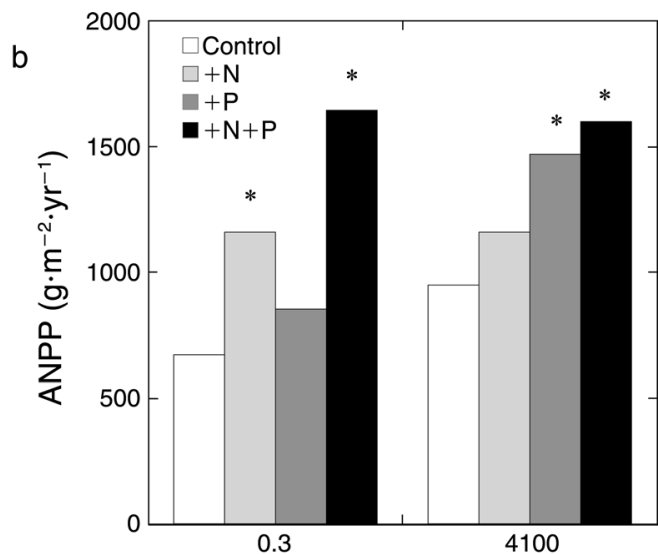

Substrate age (kyr)

C

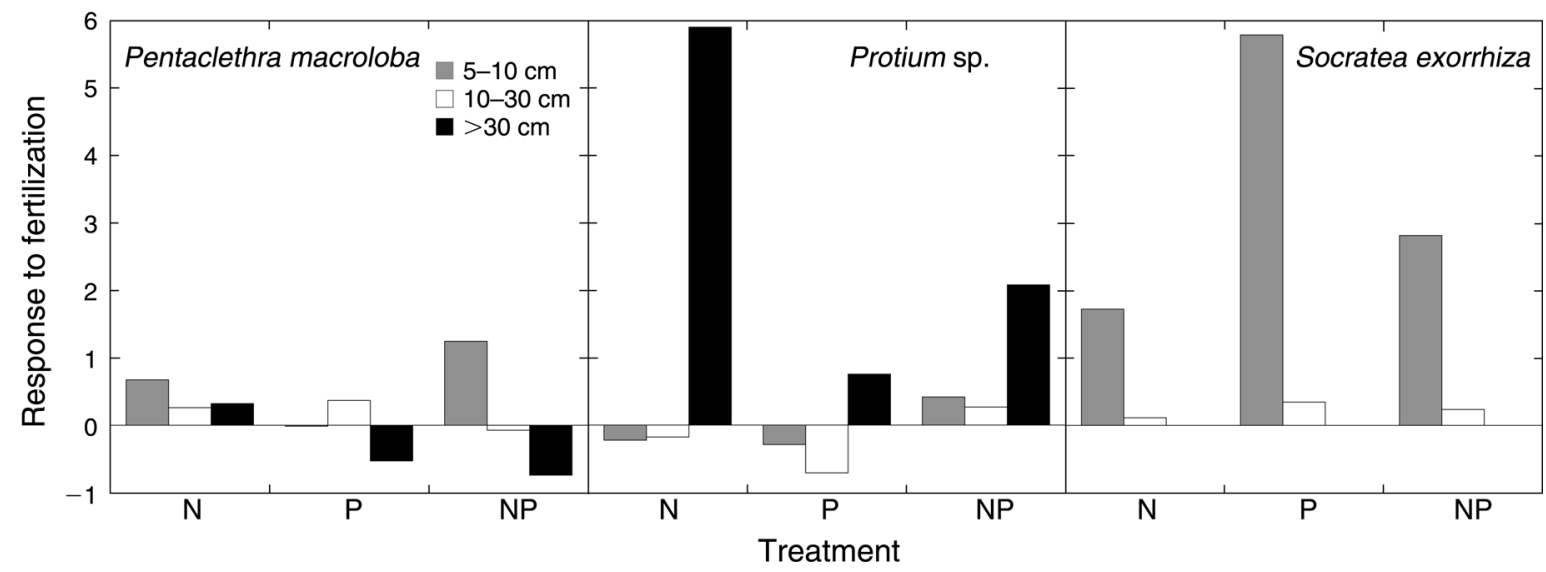

FIG. 1. Fertilization is widely considered to be the most robust method of measuring nutrient limitation. (a) Of 1069 fertilization studies identified by Elser et al. (2007), the majority assessed nutrient limitation in freshwater ecosystems. Of those conducted in terrestrial ecosystems, most were performed in sites with relatively short vegetation stature. The number of studies in each category are given in parentheses. (b) Aboveground net primary productivity (ANPP) at the youngest and oldest sites that comprise the Long Substrate Age Gradient (LSAG) in Hawaii, USA (modified from Harrington et al. [2001]). At each site, ANPP was measured on unfertilized (control) plots and plots fertilized with nitrogen $(+\mathrm{N})$, phosphorus $(+\mathrm{P})$, or nitrogen and phosphorus in combination $(+\mathrm{N}+\mathrm{P})$. Bars represent means, and asterisks indicate significant differences $(P=0.05)$ in ANPP between fertilized and unfertilized plots. $1 \mathrm{kyr}=1000 \mathrm{yr}$. (c) In a lowland tropical forest, adjacent trees responded differently to fertilizer addition depending on their size class (measured as dbh; modified from Alvarez-Clare et al. [2013]). The different response to N, P, and combined $\mathrm{N}$ and $\mathrm{P}$ (NP) fertilization among size classes is shown as mean response ratio, determined from the relative growth rate, on three common tree genera.

nutrient limitation and ask whether these alternative methods can tell us something about the nutrient limitation of ecosystem-wide NPP. We address this question, in part, using a case study of Hawaiian ecosystems where many of these methods have been applied. We focus on the application of these methods to assess the two most commonly limiting nutrients, $\mathrm{N}$ and P (Elser et al. 2007, Lebauer and Treseder 2008, Harpole et al. 2011) because most methods focus on those elements and there is sound biogeochemical theory to suggest that they may often limit production in terrestrial ecosystems. We recognize that other nutrients such as potassium (K), calcium $(\mathrm{Ca})$, sulfur $(\mathrm{S})$, and micronutrients may limit NPP, and note that some of the methods we describe could be extended to nutrients beyond $\mathrm{N}$ and $\mathrm{P}$ (Cuevas and Medina 1988, Kaspari et al. 2008, Wright et al. 2011). Next, we focus on NPP because of its fundamental importance to ecosystem function, and because it is the response variable of interest for coupled carbon-nutrient earth system models (e.g., Thornton et al. 2007). We do not argue for any method or set of methods as replacements for fertilization experiments. Rather, our goal is simply to explore the efficacy of some common alternative methods, their strengths, and their limitations. Finally, we organize our synthesis around the use of these methods in tropical forests, a critically important yet poorly understood biome where investigators confront numerous impediments to measuring nutrient limitation (Kaspari et al. 


\section{Approaches to measure nutrient limitation:}

At one site

Nutrient manipulation required
At two or more sites (relative)

Nutrient manipulations and observations possible

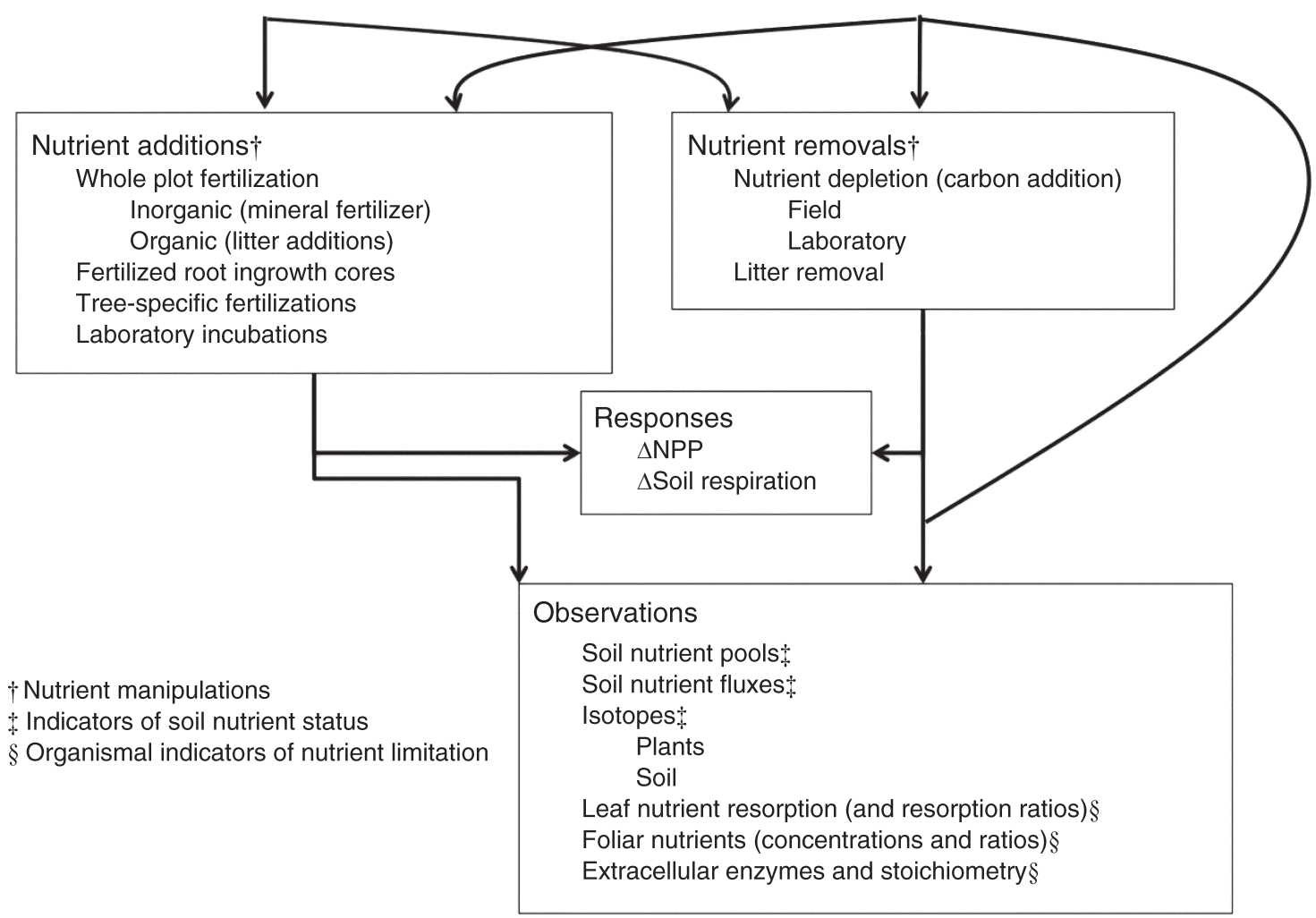

FIG. 2. The nutrient limitation toolbox. If the research question involves only one site, experimental methods should be used. If the research question involves two or more research sites and the relative difference in nutrient limitation among the sites, observational methods may be considered without experimental methods, although combining gradients of nutrient limitation and experimental methods has long been considered ideal for measuring nutrient limitation (Chapin et al. 1987). Typically, in situ studies focus on the response of NPP or soil respiration to experimental manipulations of nutrient availability. We distinguish among three groups of methods in the toolbox: indicators of soil nutrient supply, organismal indicators of nutrient limitation, and nutrient manipulations, including in situ fertilization, laboratory incubations, and nutrient depletions.

2008, Townsend et al. 2008, 2011, Quesada et al. 2009, Porder and Hilley 2011, Townsend and Asner 2013).

\section{The Alternative Methods}

We identified eight methods (besides large-scale in situ fertilization) commonly used to assess nutrient limitation of $\mathrm{N}$ and $\mathrm{P}$ and divided them into three categories (Fig. 2): (1) indicators of soil nutrient supply, or methods that usually involve measuring rates of nutrient transformations and indicators of whole-ecosystem nutrient demand; (2) organismal indicators, including methods that assess the nutrient content of organisms (such as foliar N:P ratios), or those that provide information on biological nutrient acquisition strategies; and (3) lab-based experiments and nutrient depletions, which provide direct experimental evidence of nutrient limitation, but at a different scale than in situ nutrient additions of large-scale plots (lab-based experiments) or by reducing the relatively availability of nutrients (nutrient depletions).

\section{Indicators of soil nutrient supply}

From its earliest ecological definitions, nutrient limitation has often been conflated with soil nutrient supply to plants (Chapin et al. 1986). Analyzing soil nutrient concentrations is the most straightforward approach for assessing the size of a soil nutrient pool at a given time, but nutrient pool sizes and supply rates are not necessarily correlated (Hart and Binkley 1985), and it is the rate of nutrient supply that matters most in the context of nutrient limitation (Hart et al. 1994). Nitrogen, in particular, has numerous fluxes and a stable isotope that allow ample opportunities to measure $\mathrm{N}$ supply. On the other hand, fewer opportunities exist to measure P supply, because $\mathrm{P}$ is far less mobile in soil than $\mathrm{N}$, lacks a significant gas phase, is readily sorbed to soil minerals, and does not have a stable isotope that could easily be used to 

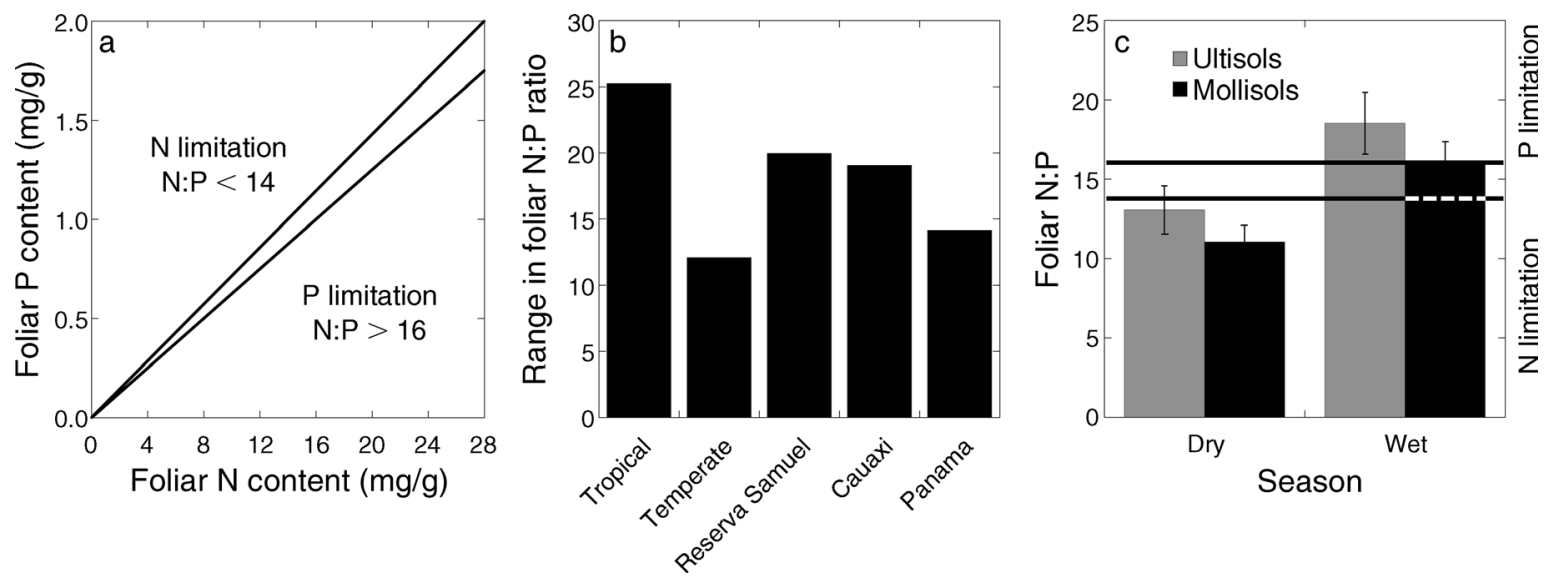

FIG. 3. Ratios of foliar nitrogen $(\mathrm{N})$ to phosphorus $(\mathrm{P})$ concentrations used for assessing nutrient limitation. (a) Foliar N:P ratios less than 14 were found in N-limited sites; foliar N: P ratios greater than 16 were found in P-limited sites (modified from Koerselman and Meuleman [1996]). (b) The range of foliar N:P ratios reported among species at three tropical sites (Reserva Samuel, Brazilian Amazon [Martinelli et al. 2000]; Cauaxí, Brazilian Amazon [Townsend et al. 2007]; Panama Canal Watershed, Panama [Santiago et al. 2005]) was greater than the range of foliar N:P ratios in the temperate biome (modified from Townsend et al. [2007]). (c) Foliar N:P ratios, averaged among all species (mean and SE), vary seasonally within sites in two different soil orders in Costa Rican tropical forests in a way that would change the interpretation of the site from $\mathrm{N}$ to $\mathrm{P}$ limited based on the Koerselman and Meuleman (1996) thresholds. Horizontal lines represent N:P ratios equal to 14 and 16, indicative of N limitation and P limitation, respectively (modified from Townsend et al. [2007]).

trace its movement through ecosystems (Falkowski et al. 2008, Syers et al. 2008). Therefore, we focus on N supply. Fortunately, plants and microbes often access the same $\mathrm{N}$ pools, and rates of microbial $\mathrm{N}$ cycling that suggest high microbial $\mathrm{N}$ availability also suggest high plant $\mathrm{N}$ availability (Kaye and Hart 1997). Large microbial N fluxes ( $\mathrm{N}$ mineralization, nitrification, and denitrification) are usually interpreted as indicating $\mathrm{N}$ availability in excess of plant and microbial demand (Vitousek and Reiners 1975, Hall and Matson 2003, Hedin et al. 2003, Brookshire et al. 2012a, b). Because most biologically mediated $\mathrm{N}$ fluxes are fractionating processes (Knowles and Blackburn 1993, Högberg 1997), N isotopes have been used repeatedly as a metric of $\mathrm{N}$ status at large and small spatial scales (Martinelli et al. 1999, Nardoto et al. 2008). Soil $\delta^{15} \mathrm{~N}$ has been used to predict the rate of global terrestrial $\mathrm{N}$ losses via denitrification (Houlton and Bai 2009). At the plot level, variation in plant and soil $\delta^{15} \mathrm{~N}$ across both a semiarid (Selmants and Hart 2008) and montane tropical (Martinelli et al. 1999) substrate age gradient supported the biogeochemical theory that $\mathrm{N}$ availability increases over millions of years of soil development. Changes in $\delta^{15} \mathrm{~N}$ over time can also indicate rates of $\mathrm{N}$ cycling, and by extension, $\mathrm{N}$ availability (e.g., Holtgrieve et al. 2011, McLauchlan et al. 2013). In tropical forests, for example, 40 years of change in $\delta^{15} \mathrm{~N}$ suggested that anthropogenic $\mathrm{N}$ deposition increased $\mathrm{N}$ availability; $\delta^{15} \mathrm{~N}$ increased in a manner similar to fertilization experiments (Hietz et al. 2011).

\section{Organismal indicators of nutrient limitation}

Plants and soil organisms have many strategies for surviving under either temporarily or chronically low nutrient conditions (Mooney et al. 1991), and ecologists have sought to utilize these strategies to assess nutrient limitation. Perhaps the clearest declaration of a need, and potential, for using plant nutrient conservation strategies as an alternative to fertilization experiments comes from Koerselman and Meuleman (1996), who described foliar nutrient ratios as a "quick and simple alternative to laborious fertilization experiments." The biological principle underlying the link between nutrient limitation and foliar nutrient ratios is straightforward: Plants have fairly specific stoichiometric requirements for nutrients (especially N and P [McGroddy et al. 2004, Reich and Oleksyn 2004]), with an average ratio of $\sim 15$. Koerselman and Meuleman (1996) synthesized foliar nutrient ratio data paired with fertilization studies in freshwater wetland ecosystems, and showed that plant communities with foliar N:P ratios $>16$ (mass basis) responded to $\mathrm{P}$ fertilization (i.e., were $\mathrm{P}$ limited), while $\mathrm{N}$-limited plants had foliar N:P ratios $<14$ (Fig. 3a). Not surprisingly, many investigators have subsequently used these foliar N:P thresholds to describe the nutrient status of their sites, but often without parallel nutrient fertilization experiments necessary to validate these thresholds.

Despite the apparent logic of this approach, however, the relationship between foliar N:P ratios and soil nutrient status is not always straightforward. For example, ecosystems experience profound shifts in $\mathrm{N}$ and $\mathrm{P}$ availability over time, but those changes are not always matched by parallel changes in foliar N:P. Across the 120000-year Franz Joseph Chronosequence in New Zealand, angiosperm foliar N:P ratios only rose from 14 to 16 , despite an almost eightfold decrease in soil $\mathrm{P}$ from the youngest to the oldest site (Stevens 1968, Walker and Syers 1976). Specifically, conifers increased their foliar 
$\mathrm{N}: \mathrm{P}$ from 8 to 16 , and fern $\mathrm{N}: \mathrm{P}$ ratios remained invariant (13-14; Richardson et al. 2005). In a tropical secondary succession chronosequence that otherwise had consistent patterns of increasing $\mathrm{N}$ availability with increasing forest age, foliar N:P ratios did not change during succession (Davidson et al. 2007). And in at least one desert ecosystem (containing only two plant species), foliar nutrient ratios failed to accurately predict nutrient limitation as assessed by fertilization experiments (Drenovsky and Richards 2004).

In addition to foliar nutrient ratios, estimates of nutrient resorption are commonly cited as potential indicators of plant nutrient demand and limitation (e.g., Vitousek 1982, 1984, McGroddy et al. 2004, Reed et al. 2012). Nutrient resorption, or the retranslocation of foliar nutrients from plant leaves prior to abscission, is an important plant nutrient conservation strategy that can affect ecosystem processes ranging from plant productivity to litter decomposition (Killingbeck 1996). Resorption is "efficient" when the energy required to remove nutrients from foliage exceeds the energy required to obtain nutrients from the soil. While the utility of resorption for determining nutrient status and limitation has been questioned, partly because of weak relationships between leaf nutrient status and leaf nutrient resorption (Aerts 1996), Reed et al. (2012) recently suggested that the relative resorption of $\mathrm{N}$ and $\mathrm{P}$ may improve the utility of resorption methods. For example, in a lowland tropical forest where $\mathrm{P}$ limitation of multiple ecosystem processes has been observed using several methods, relative $\mathrm{P}$ resorption consistently exceeded that for $\mathrm{N}$, despite significant variation in resorption efficiencies among species (Reed et al. 2012).

Belowground, fertilized root ingrowth cores have been used for several decades as an indirect test of nutrient limitation in forests (Cuevas and Medina 1988, Stewart 2000, Graefe et al. 2010). The theory is that, relative to unfertilized (control) cores, roots will proliferate into cores rich in nutrients that plants need, and grow less, or not at all, into cores with nutrients that are in relative excess in the system. The method is also straightforward: either native soil or an artificial substrate is treated with water, $\mathrm{N}$, P, or $\mathrm{K}$, placed in perforated plastic cylinders and left in the soil for several months. At the end of the experiment, cores are collected and root biomass in the various treatments is assessed. Despite their relative simplicity, inferring nutrient limitation of NPP from ingrowth core results is more complicated than commonly acknowledged, and three assumptions have yet to be conclusively justified: (1) roots will preferentially grow into a core that is fertilized with the most limiting nutrient, (2) root biomass is a sufficient assay of plant response, (3) total root biomass in cores represents a whole-community response to fertilization, and thus represents a response analogous to an NPP response to fertilization.

There is some evidence for assumption 1 where $\mathrm{N}$ limits primary production (Raich et al. 1994) but evidence is lacking from P-limited sites. Supporting evidence for assumptions 2 and 3 is scant. Nevertheless, if additional data suggest that root ingrowth responses parallel those of ANPP to fertilization, this assay may prove useful in assessing nutrient limitation across larger spatial scales than are feasible with whole-forest fertilizations.

Nutrient mineralization via extracellular enzymes is, like resorption, a mechanism through which organisms can recycle essential and potentially limiting nutrients, but is one that occurs at the interface of plant roots and within bulk soil. Both plants and soil microorganisms can synthesize a suite of extracellular enzymes that liberate organically bound nutrients and return them to the active (biologically available) pool, where they can then be immobilized or taken up by plants (Sinsabaugh 1994). Most enzymes mineralize specific nutrients (McGill and Cole 1981, Sinsabaugh and Follstad Shah 2012) and thus enzyme activity may vary directly with demand for a specific nutrient (e.g., N, P, or S [McGill and Cole 1981, Sinsabaugh et al. 1993, Sinsabaugh and Moorhead 1994]). The link between extracellular enzyme activity and nutrient demand is most robust for $\mathrm{P}$, while relationships between $\mathrm{N}$ enzyme activity and $\mathrm{N}$ demand are weaker. For example, multiple studies have shown that phosphatase enzyme activity increases with soil age, reflecting declines in soil $\mathrm{P}$ that commonly occur over long-term ecosystem development (e.g., Olander and Vitousek 2000, Treseder and Vitousek 2001, Allison et al. 2007, Selmants and Hart 2010, Sjogersten et al. 2011). But while results generally show weak correlations between $\mathrm{N}$ availability and $\mathrm{N}$ acquiring enzyme activity (reviewed by Sinsabaugh and Follstad Shah 2012), allocation theory would suggest that the relative investment in the production of $\mathrm{N}$ - vs. P-acquiring enzymes might indicate nutrient demand. Therefore, as with resorption, a stoichiometric approach to measuring extracellular enzyme activity has been suggested as an index of relative resource demand (Sinsabaugh et al. 2008), and thus may provide insight into relative nutrient limitation.

\section{Lab-based experiments and nutrient depletions}

Correlations between soil nutrients, plants, the soil microbial community, and ecosystem processes such as NPP may allow inference about nutrient limitation in an ecosystem, but causation can only be established by conducting manipulative experiments. Laboratorybased fertilizations avoid some of the issues of scale associated with in situ fertilization experiments while still providing a manipulative tool. Laboratory soil incubation experiments, performed in combination with nutrient manipulation, have been used to assess nutrient controls over soil heterotrophic activity (e.g., Amador and Jones 1993, Gallardo and Schlesinger 1994, Ilstedt and Singh 2005, Ehlers et al. 2010). Such approaches commonly involve adding labile $\mathrm{C}$, as well as nutrients, to soils in in a full factorial design, and assessing 
respiratory responses. As with the other methods, the fertilization-incubation approach may not be equally appropriate for all limiting nutrients, but it has successfully distinguished $\mathrm{P}$ constraints on microbial activity in P-limited and non-P-limited ecosystems (Cleveland et al. 2006, Cleveland and Townsend 2006, Bradford et al. 2008). Incubations also repeatedly demonstrated that $\mathrm{N}$ limitation of heterotrophic activity is not necessarily aligned with $\mathrm{N}$ limitation of aboveground NPP measured in situ with fertilization (Burton et al. 2004, DeForest et al. 2004, 2005, Pregitzer et al. 2008, Cusack et al. 2010, 2011). Therefore, microbial responses to $\mathrm{N}$ additions may not predict aboveground NPP responses; microbial responses to $\mathrm{P}$ addition may be a better predictor of aboveground NPP, but there has been little research in this area (but see discussion of Reed et al. [2011] in The efficacy of the alternatives: The Hawaiian Long Substrate Age Gradient as a case study).

Unless increases in atmospheric $\mathrm{N}$ deposition stoichiometrically outpace the increase in atmospheric $\mathrm{CO}_{2}$ (which would cause substantial other well known problems, e.g., Matson et al. [1999]), atmospheric $\mathrm{CO}_{2}$ concentrations will make nutrients less abundant relative to $\mathrm{C}$ in most ecosystems (Hungate et al. 2003). Evidence of this comes from elevated atmospheric $\mathrm{CO}_{2}$ experiments, which generally cause $\mathrm{C}$ : nutrient ratios to increase in both above- and belowground plant tissue (Luo et al. 2006), suggesting that nutrient limitation may be enhanced in a $\mathrm{CO}_{2}$-enriched atmosphere. If elevated $\mathrm{CO}_{2}$ does reduce nutrient availability, a more informative experimental approach to assess nutrient limitation (in this context) would be to reduce nutrient concentrations below ambient levels and measure plant responses. Such experiments have been termed "nutrient-depletion experiments" and are often carried out by adding $\mathrm{C}$ rich substrates to soil either in the laboratory or the field (Eviner et al. 2000). However, they are less common than nutrient addition experiments. The goal of adding $\mathrm{C}$ substrate to soil is to reduce the relative abundance of nutrients by increasing the immobilization of limiting nutrients (Magill and Aber 2000, Dijkstra et al. 2008), thus depleting plant available pools. Heterotrophic microbes utilize labile $\mathrm{C}$ as a substrate to increase metabolic activity or biomass (Fontaine et al. 2003) and must immobilize $\mathrm{N}$ and $\mathrm{P}$ to maintain stoichiometric balance from existing nutrient pools and soil organic matter (SOM) (Cleveland and Liptzin 2007). Simple sugars (e.g., glucose) and more recalcitrant forms of $\mathrm{C}$ (e.g., cellulose in the form of sawdust) are two common examples of $\mathrm{C}$ substrates added to soil to induce nutrient limitation.

Most nutrient-depletion experiments performed to date have measured the effects of $\mathrm{C}$ additions on $\mathrm{N}$ availability (but see Yarie and Van Cleve 1996, Bradford et al. 2008). In fact, many nutrient-depletion experiments are not performed by biogeochemists or plant physiologists but rather by restoration ecologists trying to reduce $\mathrm{N}$ availability. Nitrogen limitation induced by
$\mathrm{C}$ addition can inhibit invasive species and promote the reestablishment of native species capable of surviving in low-nutrient environments (reviewed by Perry et al. 2010). The application of this experimental technique to high-value ecosystems is perhaps the best evidence that $\mathrm{C}$ additions can be used to observe ecosystem-level effects of nutrient depletion. But $\mathrm{C}$ additions do not always produce the desired effects, and so should be applied cautiously. For example, a phenomenon known as "priming" can result in the mineralization, rather than immobilization, of plant-available $\mathrm{N}$ from organic matter. The conditions under which priming occur are still being explored (Kuzyakov 2002, Fontaine et al. 2003, Sullivan and Hart 2013).

The Efficacy of the Alternatives: The Hawailan Long Substrate Age Gradient as a Case Study

Individually, each of the above methods may provide some insight into nutrient limitation without the use of in situ fertilization experiments. However, their collective ability to resolve nutrient limitation has not been examined, and it remains unclear if or how they predict nutrient limitation. Therefore, we assembled data from previously published studies conducted within the Long Substrate Age Gradient (LSAG), a 4.1-million-year-old primary succession chronosequence in the Hawaiian Archipelago. The LSAG exhibits well-documented shifts in soil $\mathrm{N}$ and $\mathrm{P}$ availability over the course of soil development (Crews et al. 1995, Vitousek et al. 1997) consistent with the Walker and Syers (1976) model of ecosystem development: relative $\mathrm{N}$ availability is lower at young sites, while relative $\mathrm{P}$ availability is lower at older sites (Chadwick et al. 1999, Vitousek 2004). Hence, the LSAG represents a gradient of nutrient supply and limitation to NPP against which we can compare many of the indices we have discussed (Fig. 1b; Chapin et al. 1986, Harrington et al. 2001).

We used published values of gross $\mathrm{N}$ mineralization and nitrification (Crews et al. 1995), hydrologic and gaseous N losses (Hedin et al. 2003), and soil and foliar $\delta^{15} \mathrm{~N}$ (Martinelli et al. 1999) from an unfertilized young site $(0.3 \mathrm{kyr})$ and old site $(4100 \mathrm{kyr})$ on the LSAG to establish observational evidence of nutrient status on these two sites (Table 1). Next, from both unfertilized and fertilized treatments within the sites on the LSAG, we used published patterns of foliar N:P ratios and resorption (Vitousek 1998), root ingrowth (Raich et al. 1994), root phosphatase enzyme activity (Treseder and Vitousek 2001), and the ratio of $\mathrm{N}$ - to P-acquiring enzyme activity in bulk soil (Olander and Vitousek 2000) as indices of plant and soil microbial responses to nutrient limitation. Finally, we used evidence from laboratory-based soil and litter incubations that measured soil respiration (Reed et al. 2011) as experimental evidence of nutrient limitation. Unfortunately, no nutrient-depletion experiments were available to compare to these other methods on the LSAG. The trends of these methods between the N-limited young site and P- 
TABLE 1. Fluxes of nitrogen $(\mathrm{N})$ and the ${ }^{15} \mathrm{~N}$ pool of soil and plant leaves on the Long Substrate Age Gradient (LSAG) in Hawaii, USA.

\begin{tabular}{lccc}
\hline \hline & \multicolumn{2}{c}{ Substrate age } & \\
\cline { 2 - 3 } \multicolumn{1}{c}{$\mathrm{N}$ flux $/$ pool } & $0.3 \mathrm{kyr}$ & $4100 \mathrm{kyr}$ & \\
\hline Gross mineralization $\left(\mathrm{mg} \mathrm{N} \cdot \mathrm{m}^{-2} \cdot \mathrm{d}^{-1}\right)$ & 196 & 647 & Source \\
Gross nitrification $\left(\mathrm{mg} \mathrm{N} \cdot \mathrm{m}^{-2} \cdot \mathrm{d}^{-1}\right)$ & 3.3 & 14.4 & Crews et al. (1995) \\
Hydrologic losses $(\mu \mathrm{g} \mathrm{N} / \mathrm{L})$ & 81.2 & 366.6 & Hedin et al. (1995) \\
Gaseous losses $\left(\mathrm{ng} \mathrm{N} \cdot \mathrm{cm}^{-2} \cdot \mathrm{h}^{-1}\right)$ & 0 & 2.2 & Hedin et al. (2003) \\
${ }^{15} \mathrm{~N}$ signature $(\% 0)$ & & & Martinelli et al. (1999) \\
Surface soil & -2.2 & 0.3 & \\
Metrosideros polymorpha & -9.2 & -1.2 & \\
\hline
\end{tabular}

limited old site provide one indicator of the success of inferring nutrient limitation, but because the LSAG sites have full-factorial $\mathrm{N}$ and $\mathrm{P}$ fertilizations, we also explored whether these methods are sensitive to changes in the nutrient status caused by experimental manipulations. However, because these results have been previously published, we provide only brief descriptions; more thorough descriptions can be found in the relevant primary literature or in a description of the LSAG (synthesized in Vitousek [2004]).

Observational methods, such as soil nutrient fluxes and $\mathrm{N}$ isotope values on unfertilized plots, accurately reflected N limitation of NPP (measured by in situ fertilization [Harrington et al. 2001]) at the young site, but little or no N limitation of NPP at the old site (Table 1). Generally, other belowground methods used to assess nutrient limitation also successfully represented greater $\mathrm{N}$ limitation at the young site and greater $\mathrm{P}$ limitation at the old site (Fig. 4). Specifically, patterns of nutrient limitation in the soil microbial community were consistent with aboveground NPP, when soil microbial nutrient limitation was measured using a modified substrate induced growth response (SIGR) laboratory incubation (Cleveland et al. 2003, Reed et al. 2011). While microbial growth rates reflected both $\mathrm{N}$ and $\mathrm{P}$ limitation, root phosphatase enzyme activity was significantly higher in unfertilized plots at the old site than the young site (Treseder and Vitousek 2001), and root phosphatase enzyme activity increased in $\mathrm{N}$ fertilized plots and decreased in P-fertilized plots (Fig. 4). Root ingrowth cores indicated $N$ limitation at the young site, where root biomass in $\mathrm{N}$-fertilized cores increased relative to unfertilized or P-fertilized cores (Raich et al. 1994, Fig. 4). There was no analogous response at the old site, perhaps because the artificial soil used in the cores (Turface, Buffalo Grove, Illinois, USA) contained substantially more $\mathrm{P}$ than the native soils (J. W. Raich, unpublished data; L. Schreeg, unpublished data). Finally, the ratio of $\mathrm{N}$ - to P-acquiring enzyme activity (calculated from Olander and Vitousek [2000]) was substantially lower at the old site relative to the young site in both the soil $\mathrm{O}$ and $\mathrm{A}$ horizons. This pattern was driven by chitinase activity, however, and not phosphatase activity. However, soil enzyme activity ratios did respond to fertilization experiments in predictable ways in the $\mathrm{O}$ horizon at both sites: $\mathrm{N}$ fertilizations increased P-acquiring enzyme activity relative to $\mathrm{N}$-acquiring enzyme activity by inducing $\mathrm{P}$ limitation, $\mathrm{P}$ fertilization increased $\mathrm{N}$-acquiring enzyme activity relative to $\mathrm{P}$-acquiring enzyme activity by inducing $\mathrm{N}$ limitation, and $\mathrm{N}+\mathrm{P}$ fertilizations caused no relative shift in $\mathrm{N}$ - or $\mathrm{P}$-acquiring enzyme activity (Fig. 4). In the mineral soil, $\mathrm{P}$ fertilization had the strongest effect at the P-limited old site (Fig. 4).

Aboveground plant foliar metrics were less consistent with nutrient limitation than the belowground methods described above. Foliar N:P ratios on unfertilized plots increased between the young and old sites (from 12.0 to 15.4), consistent with $P$ limitation at the old site. Yet this change was driven by an increase in foliar $\mathrm{N}$, not a decrease in foliar $\mathrm{P}$, at the old site relative to the young site (Vitousek 1998). The effect of fertilization on foliar $\mathrm{N}: \mathrm{P}$ ratios was also not consistent with nutrient limitation. At the N-limited young site, foliar N:P ratios increased on $\mathrm{N}$-fertilized plots, consistent with theory, but $\mathrm{P}$ fertilization reduced $\mathrm{N}: \mathrm{P}$ ratios at both the young site and the P-limited old site (Fig. 4). Similarly, foliar resorption patterns were not strongly consistent with patterns of nutrient limitation measured by NPP responses to fertilization. Foliar resorption of $\mathrm{N}$ was not particularly sensitive to either substrate age or fertilization treatment in a way that would be expected based on biogeochemical theory (Fig. 4). Foliar P resorption was not sensitive to substrate age or fertilization treatments at the young site, but was lower on P-fertilized plots at the P-limited old site (Fig. 4).

None of the above methods, by themselves, concretely establishes relative nutrient limitation between the LSAG sites. Nonetheless, the collective information gleaned from these approaches demonstrates that these methods, in combination, provide useful and credible evidence of nutrient limitation to NPP. In total, 12 of the 15 analyses that used these methods indicated nutrient limitation, either among sites or in response to long-term fertilizer amendment (Table 1, Fig. 4). Importantly, these methods also reflect forms of nutrient limitation that are less apparent from fertilization experiments alone. For example, foliar nutrient limitation may be different than belowground nutrient limitation, and belowground nutrient limitation and 

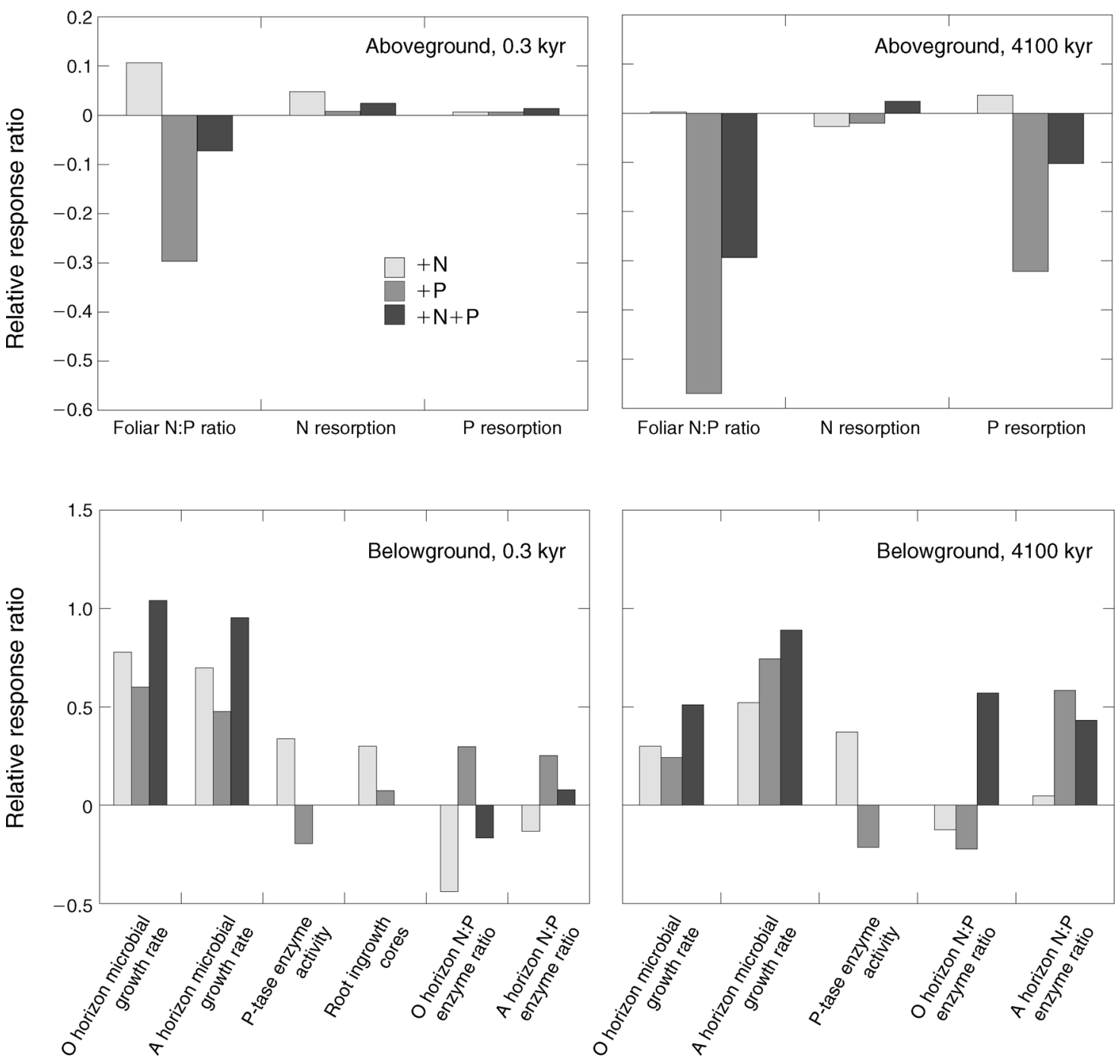

FIG. 4. Side-by-side comparison of results obtained using three aboveground methods and six belowground methods that are part of the nutrient limitation toolbox and were used on the Long Substrate Age Gradient (LSAG) of Hawaii. Results are depicted as effect sizes (relative response ratios $=\ln$ [fertilized/control]); Elser et al. [2007]) and show the change in each method caused by long-term fertilization with nitrogen $(\mathrm{N})$, phosphorus $(\mathrm{P})$, or $+\mathrm{N}+\mathrm{P}$. The LSAG included several sites occupying a naturally occurring gradient of $\mathrm{N}$ and $\mathrm{P}$ availability, but we depict data from only the youngest and oldest sites here. The $0.3-\mathrm{kyr}$ site had lower $\mathrm{N}$ and greater $\mathrm{P}$ availability than the $4100-\mathrm{kyr}$ site, and fertilization experiments demonstrated N-limited ANPP at the 0.3kyr site and P-limited ANPP at the 4100-kyr site (Harrington et al. 2001; Fig. 1b). Statistical differences are not reported due to the lack of replication and inconsistent statistical approaches taken among the studies that reported these values. The abbreviation "Ptase" indicates root phosphatase. Relative response ratios were calculated from data originally presented in Vitousek (1998) (foliar N:P ratios and N and P resorption), Reed et al. (2011) (O and A horizon microbial growth rates), Treseder and Vitousek (2001) (Ptase enzyme activity), Raich et al. (1994) (root ingrowth cores), and Olander and Vitousek (2000) (O and A horizon N:P enzyme ratios).

nutrient constraints of NPP may be linked (Reed et al. 2011).

\section{Nutrient limitation in diverse tropical forests}

The case study from Hawaii suggests that nutrient limitation of NPP can be assessed using many of the alternative methods available. However, the LSAG represents a unique circumstance of nutrient limitation in tropical forests, for its forests have low tree diversity compared to continental tropical forests or islands less isolated than the Hawaiian archipelago (Vitousek 2004). Though substantial direct evidence exists for nutrient limitation in montane forests (Tanner et al. 1998) where fertilization responses have been shown to occur relatively rapidly (Homeier et al. 2012), nutrient responses in lowland forests often occur more slowly and thus the true nature of nutrient limitation is much less clear (Townsend et al. 2008, Wright et al. 2011, Alvarez-Clare et al. 2013). The biogeochemical complexity of many lowland tropical forests is driven, at 


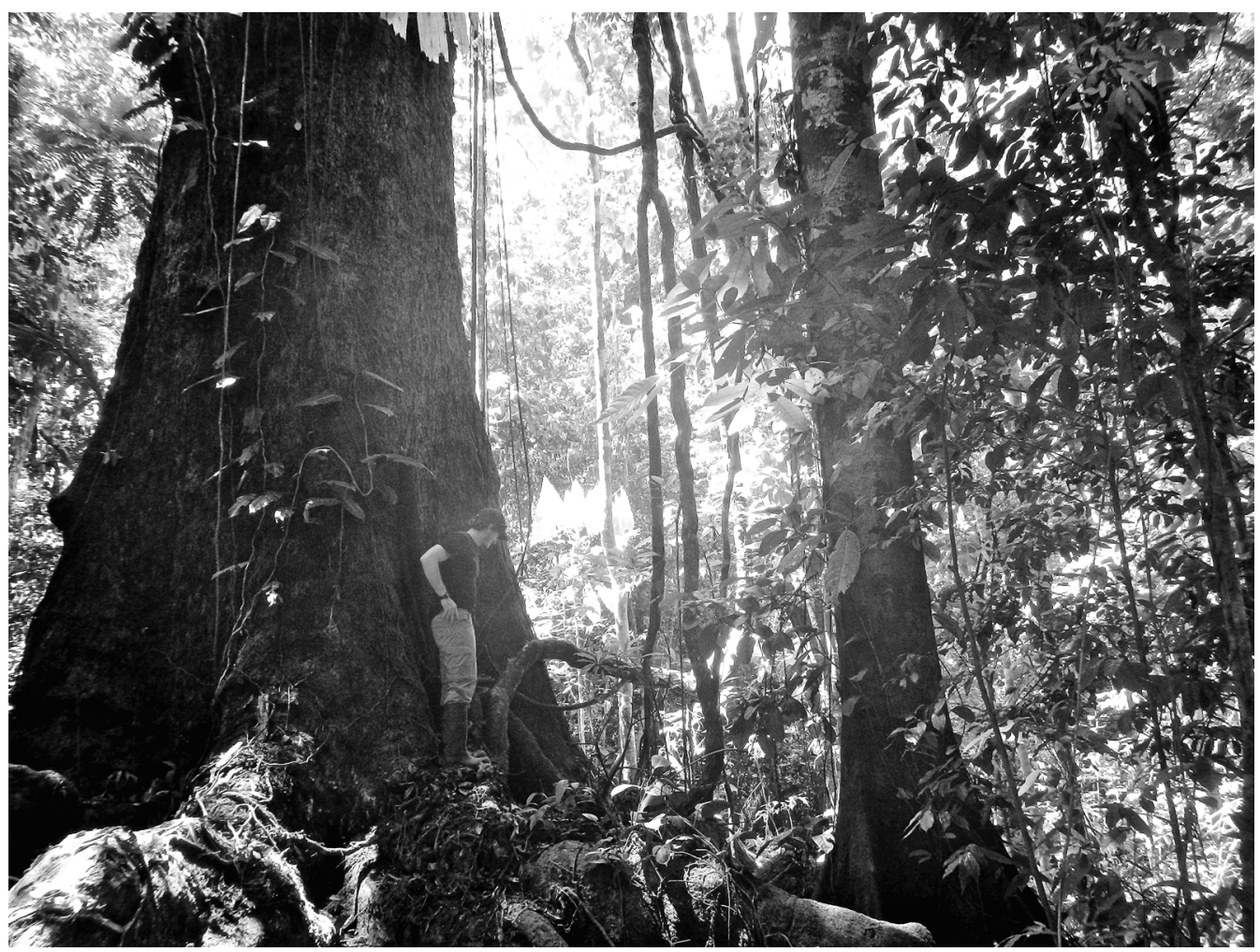

Plate 1. Only three full-factorial fertilization (nitrogen $\times$ phosphorus) experiments have been reported in complex lowland tropical rain forests such as this one in Costa Rica. These forests present significant challenges to fertilization experiments. For example, the basal area of this large ( $>3 \mathrm{~m}$ diameter) ajo tree (Caryocar costaricense) in Costa Rica is larger than the size of many fertilization plots in grassland ecosystems, and its root system is likely expansive (e.g., its buttressed roots extend for meters beyond the stem in all directions). Accurately assessing nutrient limitation in such diverse, dense, and large stature forests is costly, labor intensive, often logistically complex, and may require years to observe responses. Thus, our understanding of the nature and extent of nutrient limitation in many tropical forests is very limited. Photo credit: C. C. Cleveland.

least in part, by plant species diversity (Townsend et al. 2008), and evidence is mounting that the primary controls over canopy chemistry in tropical forests is phylogenetic rather than environmental (Fyllas et al. 2009, Asner and Martin 2011, Townsend and Asner 2013). Thus, some indicators of nutrient limitation (especially those aboveground) may not translate well from low-diversity island systems to the continental tropics. Indeed, the few extant fertilization experiments from such systems have demonstrated that nutrient limitation can vary at very small scales $(>5 \mathrm{~m})$ both among species and among size classes of trees (Fig. 1c; Alvarez-Clare et al. 2013). Therefore, an important question remains: can the methodological toolbox we describe above depict nutrient limitation in diverse continental lowland tropical forests? Some of the methods we describe have been explored in tropical ecosystems, with mixed results.

One relatively well-explored method is foliar nutrient ratios, but accumulating evidence suggests they may not reflect nutrient limitation to NPP in diverse lowland tropical forests. For example, the inter-species variability of foliar N:P ratios in tropical forests exceeded that of tree species from across the temperate zone (Fig. 3b; Townsend et al. 2007). Such variation within highdiversity forests demands quantitative integration across the entire canopy to represent a community-wide average value (Townsend et al. 2008, Asner and Martin 2011). Furthermore, foliar N:P ratios may vary over relatively short timescales (Fig. 3c; Townsend et al. 2007). Whether or not this indicates seasonal shifts in nutrient limitation is untested, and indeed untestable, with parallel fertilization experiments. The substantial small-scale spatial and temporal variability of foliar nutrient ratios could reflect heterogeneity of nutrient limitation within a tropical forest, as observed with fertilization methods (Fig. 1c). Yet it could also be misleading. Using the LSAG sites, Ostertag (2010) showed that several dominant fertilized plant species stored $\mathrm{P}$, but not $\mathrm{N}$, regardless of the fertility of the sites. Foliar nutrient ratios may be an important metric for other important biological processes in lowland tropical forests, but they may not integrate forest-level nutrient limitation of NPP due to these challenges.

Ultimately, many of the pressing questions about nutrient limitation in tropical forests seek to integrate 
across the substantial biological diversity and ask: what is most limiting to a particular forest now, and how will that change in the future? Foliar metrics appear equivocal, at best, for many of the reasons summarized above. Fortunately, belowground methods seem promising, and may do a better job of depicting broader-scale conditions. For example, using a fertilization-incubation technique with soils from a tropical rain forest site with P poor Ultisols, Cleveland et al. (2006) showed that soil heterotrophic respiration of native, leached dissolved organic matter was stimulated with $\mathrm{P}$ additions, and suppressed with $\mathrm{N}$ additions, consistent with observed in situ increases in $\mathrm{CO}_{2}$ losses with $\mathrm{P}$ fertilization (Cleveland and Townsend 2006). Based on these results, Cleveland et al. (2006) suggested that low soil P availability strongly regulates the fate of dissolved organic matter leached from the litter layer to soils, with higher $\mathrm{P}$ decreasing the proportion of leached $\mathrm{C}$ that is likely to be stored in soil. Similarly, using a soil microcosm experiment with a low-fertility Ultisol from the southeastern United States, Bradford et al. (2008) showed enhanced soil organic $\mathrm{C}$ decomposition with added $\mathrm{P}$, suggesting that $\mathrm{P}$ availability regulates belowground $\mathrm{C}$ storage in this site as well. Finally, in a tropical forest site in Costa Rica, Reed et al. (2007) showed that rates of heterotrophic dinitrogen $\left(\mathrm{N}_{2}\right)$ fixation were strongly enhanced with $\mathrm{P}$ fertilization, and that rates of litter-layer $\mathrm{N}_{2}$ fixation were strongly correlated with litter P availability (Reed et al. 2008). Together, these data suggest that rates of heterotrophic activity in these ecosystems are $\mathrm{P}$ limited, and provide a plot-level indication of $\mathrm{P}$ limitation. Efforts to connect such belowground nutrient limitation information with indications of aboveground nutrient limitation are recent and rare (Reed et al. 2011), but merit further attention, given successes to date.

\section{The way forward}

Several recent studies have used regression approaches and gradients of sites to establish the relationship between nutrient availability and aboveground growth in tropical forests (Baribault et al. 2012, Quesada et al. 2012, Condit et al. 2013). These studies repeatedly show sensitivity of tree growth and forest structure to multiple different soil nutrients, including $\mathrm{P}, \mathrm{K}$, and $\mathrm{Ca}$. These findings are consistent with the concept of multiple nutrient limitation (Bloom et al. 1985, Chapin et al. 1987, Rastetter and Shaver 1992), described in tropical forests by Kaspari et al. (2008) and Townsend et al. (2011), among others. Whether it is possible to predict nutrient limitation based on the composition of a forest, however, remains to be seen; the presence of $\mathrm{N}_{2}$-fixing legumes (an important component of many tropical forests [Crews 1999]) may also disrupt relationships between soil nutrient status and tree growth and abundance (Baribault et al. 2012, Condit et al. 2013). Findings such as those described in Fyllas et al. (2009), Asner and Martin (2011), and Condit et al. (2013), among others, all underscore the need for comprehensive studies at large spatial scales that integrate variability in sites with high species diversity. That is no small challenge given the complexity of many tropical systems, though new airborne methods hold considerable promise for achieving such integration across scales as never before (Asner et al. 2012).

The need to understand nutrient limitation in the tropical biome will only grow in importance, especially as the effects of global changes on such ecosystems increases and the role of physical factors (e.g., water and temperature) on vegetation become better parameterized in climate change models (Huntingford et al. 2013). While new methods such as airborne remote sensing can provide important breakthroughs, ecologists will undoubtedly continue to rely on field-based measurements of nutrient limitation, especially within the context of remotely derived or modeled information. Ideally, we would converge on a set of metrics that could be readily applied across the kinds of complex gradients the new remote sensing methods can cover, in ways that could assess potential shifts in nutrient limitation along such gradients.

Here, we show that the methods chosen to answer such questions may affect the outcome. By examining the LSAG sites as a case study, and the application of these methods in tropical ecosystems generally, we suggest methods that measure nutrient limitation of belowground processes may provide insight into nutrient limitation without using plot-level fertilizations. Fortunately, many of these methods are fairly quick and straightforward to apply, and thus if shown to be reliable indicators across a broader array of ecosystems, may provide a useful "rapid-assessment" set of tools that can help constrain large-scale assessments of tropical forests under global change scenarios. That said, we stress that the relationship between belowground nutrient limitation and nutrient limitation of NPP needs to be more rigorously tested, in both space and time. With continued, careful evaluation and use of as many of the methods in the toolbox as possible, we may begin to understand nutrient limitation at all spatial and temporal scales in even the most diverse ecosystems on Earth.

\section{ACKNOWLEDGMENTS}

We thank two anonymous reviewers for comments on an early version of the manuscript. Grants from the Andrew W. Mellon Foundation and the National Science Foundation (NSF DEB-0919080) funded this work.

\section{Literature Cited}

Aerts, R. 1996. Nutrient resorption from senescing leaves of perennials: are there general patterns? Journal of Ecology 84 : 597-608.

Allison, V. J., L. M. Condron, D. A. Peltzer, S. J. Richardson, and B. L. Turner. 2007. Changes in enzyme activities and soil microbial community composition along carbon and nutrient gradients at the Franz Josef chronosequence, New Zealand. Soil Biology and Biochemistry 39:1770-1781.

Alvarez-Clare, S., M. C. Mack, and M. Brooks. 2013. A direct test of nitrogen and phosphorus limitation to net primary 
productivity in a lowland tropical wet forest. Ecology 94: $1540-1551$

Amador, J. A., and R. D. Jones. 1993. Nutrient limitations on microbial respiration in peat soils with different total $\mathrm{P}$ content. Soil Biology and Biochemistry 25:793-801.

Asner, G. P., D. E. Knapp, J. Boardman, R. O. Green, T. Kennedy-Bowdoin, M. Eastwood, R. E. Martin, C. Anderson, and C. B. Field. 2012. Carnegie Airborne Observatory-2: increasing science data dimensionality via high-fidelity multisensor fusion. Remote Sensing of Environment 124:454-465.

Asner, G. P., and R. E. Martin. 2011. Canopy phylogenetic, chemical, and spectral assembly in a lowland Amazonian forest. New Phytologist 189:999-1012.

Baribault, T. W., R. K. Kobe, and A. O. Finley. 2012. Tropical tree growth is correlated with soil phosphorus, potassium, and calcium, though not for legumes. Ecological Monographs 82:189-203.

Barron, A. R., N. Wurzburger, J. P. Bellenger, S. J. Wright, A. M. L. Kraepiel, and L. O. Hedin. 2008. Molybdenum limitation of asymbiotic nitrogen fixation in tropical forest soils. Nature Geoscience 2:42-45.

Bloom, A. J., F. S. Chapin, III, and H. A. Mooney. 1985. Resource limitation in plants - an economic analogy. Annual Review of Ecology and Systematics 16:363-392.

Bradford, M. A., N. Fierer, and J. F. Reynolds. 2008. Soil carbon stocks in experimental mesocosms are dependent on the rate of labile carbon, nitrogen and phosphorus inputs to soils. Functional Ecology 22:964-974.

Brookshire, E. N. J., S. Gerber, D. N. L. Menge, and L. O. Hedin. 2012a. Large losses of inorganic nitrogen from tropical rainforests suggest a lack of nitrogen limitation. Ecology Letters 15:9-16.

Brookshire, E. N. J., L. O. Hedin, J. D. Newbold, D. M. Sigman, and J. K. Jackson. 2012b. Sustained losses of bioavailable nitrogen from montane tropical forests. Nature Geoscience. http://dx.doi.org/10.1038/NGEO1372

Burton, A. J., K. S. Pregitzer, J. N. Crawford, G. P. Zogg, and D. R. Zak. 2004. Chronic $\mathrm{NO}_{3}$ additions reduce soil respiration in northern hardwood forests. Global Change Biology 10:1080-1091.

Chadwick, O. A., L. A. Derry, P. M. Vitousek, B. J. Huebert, and L. O. Hedin. 1999. Changing sources of nutrients during four million years of ecosystem development. Nature 397: 491-497.

Chapin, F. S., III. 1980. The mineral nutrition of wild plants. Annual Review of Ecology and Systematics 11:233-260.

Chapin, F. S., III, A. J. Bloom, C. B. Field, and R. H. Waring. 1987. Plant responses to multiple environmental factors. BioScience 37:49-57.

Chapin, F. S., III, P. M. Vitousek, and K. Van Cleve. 1986. The nature of nutrient limitation in plant communities. American Naturalist 127:48-58.

Cleveland, C. C., and D. Liptzin. 2007. C:N:P stoichiometry in soil: is there a "Redfield ratio" for the microbial biomass? Biogeochemistry 85:235-252.

Cleveland, C. C., S. C. Reed, and A. R. Townsend. 2006. Nutrient regulation of organic matter decomposition in a tropical rain forest. Ecology 87:492-503.

Cleveland, C. C., and A. R. Townsend. 2006. Nutrient additions to a tropical rain forest drive substantial soil carbon dioxide losses to the atmosphere. Proceedings of the National Academy of Sciences USA 103:10316-10321.

Cleveland, C. C., A. R. Townsend, S. K. Schmidt, and B. C. Constance. 2003. Soil microbial dynamics and biogeochemistry in tropical forests and pastures, southwestern Costa Rica. Ecological Applications 13:314-326.

Cleveland, C. C., et al. 2011. Relationships among net primary productivity, nutrients, and climate in tropical rain forest: a pan-tropical analysis. Ecology Letters 14:939-947.

Condit, R., B. M. J. Engelbrecht, D. Pino, R. Pérez, and B. L. Turner. 2013. Species distributions in response to individual soil nutrients and seasonal drought across a community of tropical trees. Proceedings of the National Academy of Sciences USA. http://dx.doi.org/10.1073/pnas.1218042110

Crews, T. E. 1999. The presence of nitrogen fixing legumes in terrestrial communities: evolutionary vs ecological considerations. Biogeochemistry 46:233-246.

Crews, T. E., K. Kitayama, J. H. Fownes, R. H. Riley, D. A. Herbert, D. Mueller-Dombois, and P. M. Vitousek. 1995. Changes in soil phosphorus fractions and ecosystem dynamics across a long chronosequence in Hawaii. Ecology 76:1407-1424.

Cuevas, E., and E. Medina. 1988. Nutrient dynamics within Amazonian forests. II. Fine root growth, nutrient availability and leaf litter decomposition. Acta Oecologia 76:222-235.

Cusack, D. F., W. L. Silver, M. S. Torn, and W. H. McDowell. 2011. Effects of nitrogen additions on above- and belowground carbon dynamics in two tropical forests. Biogeochemistry 104:203-225.

Cusack, D. F., M. S. Torn, W. H. McDowell, and W. L. Silver. 2010. The response of heterotrophic activity and carbon cycling to nitrogen additions and warming in two tropical soils. Global Change Biology 16:2555-2572.

Davidson, E. A., et al. 2007. Recuperation of nitrogen cycling in Amazonian forests following agricultural abandonment. Nature 447:995-998.

DeForest, J. L., D. R. Zak, K. S. Pregitzer, and A. J. Burton. 2004. Atmospheric nitrate deposition, microbial community composition, and enzyme activity in northern hardwood forests. Soil Science Society of America Journal 68:132-138.

DeForest, J. L., D. R. Zak, K. S. Pregitzer, and A. J. Burton. 2005. Atmospheric nitrate deposition and enhanced dissolved organic carbon leaching: test of a potential mechanism. Soil Science Society of America Journal 69:1233-1237.

Dijkstra, P., C. M. LaViolette, J. S. Coyle, R. R. Doucett, E. Schwartz, S. C. Hart, and B. A. Hungate. $2008 .{ }^{15} \mathrm{~N}$ enrichment as an integrator of the effects of $\mathrm{C}$ and $\mathrm{N}$ on microbial metabolism and ecosystem function. Ecology Letters 11:389-397.

Drenovsky, R. E., and J. H. Richards. 2004. Critical N:P values: predicting nutrient deficiencies in desert shrublands. Plant and Soil 259:59-69.

Ehlers, K., L. R. Bakken, A. Frostegard, E. Frossard, and E. K. Bunemann. 2010. Phosphorus limitation in a Ferralsol: impact on microbial activity and cell internal $\mathrm{P}$ pools. Soil Biology and Biochemistry 42:558-566.

Elser, J. J., et al. 2007. Global analysis of nitrogen and phosphorus limitation of primary producers in freshwater, marine, and terrestrial ecosystems. Ecology Letters 10:1135-1142.

Eviner, V. T., F. S. Chapin, III, and C. E. Vaughn. 2000. Nutrient manipulations in terrestrial ecosystems. Pages 291307 in O. E. Sala, R. B. Jackson, H. A. Mooney, and R. W. Howarth, editors. Methods in ecosystem science. SpringerVerlag, New York, New York, USA.

Falkowski, P. G., T. Fenchel, and E. F. DeLong. 2008. The microbial engines that drive earth's biogeochemical cycles. Science 320:1034-1039.

Fisher, J. B., Y. Malhi, I. C. Torres, D. B. Metcalfe, M. J. van de Weg, P. Meir, J. E. Silva-Espejo, and W. H. Huasco. 2013. Nutrient limitation in rainforests and cloud forests along a $3,000-\mathrm{m}$ elevation gradient in the Peruvian Andes. Acta Oecologia 172:889-902.

Fontaine, S., A. Mariotti, and L. Abbadie. 2003. The priming effect of organic matter: a question of microbial competition? Soil Biology and Biochemistry 35:837-843.

Fyllas, N. M., et al. 2009. Basin-wide variations in foliar properties of Amazonian forest: phylogeny, soils and climate. Biogeosciences 6:3707-3796.

Gallardo, A., and W. Schlesinger. 1994. Factors limiting microbial biomass in the mineral soil and forest floor of a warm-temperate forest. Soil Biology and Biochemistry 26: $1409-1415$ 
Gough, L., C. W. Osenberg, K. L. Gross, and S. L. Collins 2000. Fertilization effects of species density and primary productivity in herbaceous plant communities. Oikos 89: $428-439$.

Graefe, S., D. Hertel, and C. Leuschner. 2010. N, P and K limitation of fine root growth along an elevation transect in tropical mountain forests. Acta Oecologia 36:537-542.

Grimm, N. B., et al. 2003. Merging aquatic and terrestrial perspectives of nutrient biogeochemistry. Acta Oecologia 137:485-501.

Hall, S. J., and P. A. Matson. 2003. Nutrient status of tropical rain forests influences soil $\mathrm{N}$ dynamics after $\mathrm{N}$ additions. Ecological Monographs 73:107-129.

Harpole, W. S., et al. 2011. Nutrient co-limitation of primary producer communities. Ecology Letters 14:852-862.

Harrington, R. A., J. H. Fownes, and P. M. Vitousek. 2001. Production and resource use efficiencies in $\mathrm{N}$ - and P-limited tropical forests: a comparison of responses to long-term fertilization. Ecosystems 4:646-657.

Hart, S. C., and D. Binkley. 1985. Correlations among indices of forest soil nutrient availability in fertilized and unfertilized loblolly pine plantations. Plant and Soil 85:11-21.

Hart, S. C., J. M. Stark, E. A. Davidson, and M. K. Firestone. 1994. Nitrogen mineralization, immobilization, and nitrification. Pages 985-1018 in R. W. Weaver, editor. Methods of soil analysis, part 2: microbiological and biochemical properties. Soil Science Society of America, Madison, Wisconsin, USA.

Hedin, L. O., P. M. Vitousek, and P. A. Matson. 2003. Nutrient losses over four million years of tropical forest development. Ecology 84:2231-2255.

Hietz, P., B. L. Turner, W. Wanek, A. Richter, C. A. Nock, and S. J. Wright. 2011. Long-term change in the nitrogen cycle of tropical forests. Science 334:664-666.

Högberg, P. 1997. ${ }^{15} \mathrm{~N}$ natural abundance in soil-plant systems. New Phytologist 137:179-203.

Holtgrieve, G. W., et al. 2011. A coherent signature of anthropogenic nitrogen deposition to remote watersheds of the northern hemisphere. Science 334:1545-1548.

Homeier, J., et al. 2012. Tropical Andean forests are highly susceptible to nutrient inputs-rapid effects of experimental $\mathrm{N}$ and $\mathrm{P}$ addition to an Ecuadorian montane forest. PLoS ONE 7:e47128.

Houlton, B. Z., and E. Bai. 2009. Imprint of denitrifying bacteria on the global terrestrial biosphere. Proceedings of the National Academy of Sciences USA 106:21713-21716.

Hungate, B. A., J. S. Dukes, M. R. Shaw, Y. Luo, and C. B. Field. 2003. Nitrogen and climate change. Science 302:15121513.

Huntingford, C., et al. 2013. Simulated resilience of tropical rainforests to $\mathrm{CO}_{2}$-induced climate change. Nature Geoscience. http://dx.doi.org/10.1038/NGEO1741

Ilstedt, U., and S. Singh. 2005. Nitrogen and phosphorus limitations of microbial respiration in a tropical phosphorusfixing acrisol (ultisol) compared with organic compost. Soil Biology and Biochemistry 37:1407-1410.

Kaspari, M., M. N. Garcia, K. E. Harms, M. Santana, S. J. Wright, and J. B. Yavitt. 2008. Multiple nutrients limit litterfall and decomposition in a tropical forest. Ecology Letters 11:35-43.

Kaye, J. P., and S. C. Hart. 1997. Competition for nitrogen between plants and soil microorganisms. Trends in Ecology and Evolution 12:139-143.

Killingbeck, K. T. 1996. Nutrients in senesced leaves: keys to the search for potential resorption and resorption proficiency. Ecology 77:1716-1727.

Knowles, R., and T. H. Blackburn. 1993. Nitrogen isotope techniques. Academic Press, San Diego, California, USA.

Koerselman, W., and A. F. M. Meuleman. 1996. The vegetation $\mathrm{N}: \mathrm{P}$ ratio: a new tool to detect the nature of nutrient limitation. Journal of Applied Ecology 33:1441-1450.
Kuzyakov, Y. 2002. Review: factors affecting rhizosphere priming effects. Journal of Plant Nutrition and Soil Science 165:382-396.

Lawes, J. B., and J. H. Gilbert. 1880. Agricultural, botanical, and chemical results of experiments on the mixed herbage of permanent meadow, conducted for more than twenty years in succession on the same land, Part 1. Philosophical Transactions of the Royal Society of London 171:289-416.

Lebauer, D. S., and K. K. Treseder. 2008. Nitrogen limitation of net primary productivity in terrestrial ecosystems is globally distributed. Ecology 89:371-379.

Luo, Y., D. Hui, and D. Zhang. 2006. Elevated $\mathrm{CO}_{2}$ stimulates net accumulations of carbon and nitrogen in land ecosystems: a meta-analysis. Ecology 87:53-63.

Magill, A. H., and J. D. Aber. 2000. Variation in soil net mineralization rates with dissolved organic carbon additions. Soil Biology and Biochemistry 32:597-601.

Martinelli, L. A., S. Almeida, I. F. Brown, M. Z. Morerira, R. L. Victoria, S. Filoso, C. A. C. Ferreira, and W. W. Thomas. 2000. Variation in nutrient distribution and potential nutrient losses by selective logging in a humid tropical forest of Rondonia, Brazil. Biotropica 32(4a):597-613.

Martinelli, L. A., et al. 1999. Nitrogen stable isotopic composition of leaves and soil: tropical versus temperate forests. Biogeochemistry 46:45-65.

Matson, P. A., W. H. McDowell, A. R. Townsend, and P. M. Vitousek. 1999. The globalization of $\mathrm{N}$ deposition: ecosystems consequences in tropical environments. Biogeochemistry $46: 67-83$.

McGill, W. B., and C. V. Cole. 1981. Comparative aspects of cycling of organic $\mathrm{C}, \mathrm{N}, \mathrm{S}$, and $\mathrm{P}$ through soil organic matter. Geoderma 26:267-286.

McGroddy, M. E., T. Daufresne, and L. O. Hedin. 2004. Scaling of C:N:P stoichiometry in forests worldwide: implications of terrestrial Redfield-type ratios. Ecology 85: 2390-2401.

McLauchlan, K. K., J. J. Williams, J. M. Craine, and E. S. Jeffers. 2013. Changes in global nitrogen cycling during the Holocene epoch. Nature 495:352-355.

Mirmanto, E., J. Proctor, J. Green, L. Nagy, and Suriantata. 1999. Effects of nitrogen and phosphorus fertilization in a lowland evergreen rainforest. Philosophical Transactions of the Royal Society B 354:1825-1829.

Mooney, H. A., B. G. Drake, R. J. Luxmoore, W. C. Oechel, and L. F. Pitelka. 1991. Predicting ecosystem responses to elevated $\mathrm{CO}_{2}$ concentrations. BioScience 41:96-104.

Nardoto, G. B., J. P. H. B. Ometo, J. R. Ehleringer, N. Higuchi. M. M. C. Bustamante, and L. A. Martinelli. 2008. Understanding the influences of spatial patterns on $\mathrm{N}$ availability within the Brazilian Amazon forest. Ecosystems 11:1234-1246.

Olander, L. P., and P. M. Vitousek. 2000. Regulation of soil phosphatase and chitinase activity by $\mathrm{N}$ and $\mathrm{P}$ availability. Biogeochemistry 49:175-190.

Ostertag, R. 2010. Foliar nitrogen and phosphorus accumulation responses after fertilization: an example from nutrientlimited Hawaiian forests. Plant and Soil 334:85-98.

Peltzer, D. A., et al. 2010. Understanding ecosystem retrogression. Ecological Monographs 80:509-529.

Perry, L. G., D. M. Blumenthal, T. A. Monaco, M. W. Paschke, and E. F. Redente. 2010. Immobilizing nitrogen to control plant invasion. Acta Oecologia 163:13-24.

Porder, S., and G. E. Hilley. 2011. Linking chronosequences with the rest of the world: predicting soil phosphorus content in denuding landscapes. Biogeochemistry 102:153-166.

Pregitzer, K. S., A. J. Burton, D. R. Zak, and A. F. Talhelm. 2008. Simulated chronic nitrogen deposition increases carbon storage in northern temperate forests. Global Change Biology 14:142-153.

Quesada, C. A., J. Lloyd, L. O. Anderson, N. M. Fyllas, M. Schwarz, and C. I. Czmiczik. 2009. Soils of Amazonia with 
particular reference to the RAINFOR sites. Biogeosciences 6: 3851-3921.

Quesada, C. A., et al. 2012. Basin-wide variation in Amazon forest structure and function are mediated by both soils and climate. Biogeosciences 9:2203-2246.

Raich, J. W., R. H. Riley, and P. M. Vitousek. 1994. Use of root-ingrowth cores to assess nutrient limitations in forest ecosystems. Ecosystems 24:2135-2138.

Rastetter, E. B., and G. R. Shaver. 1992. A model of multipleelement limitation for acclimating vegetation. Ecology 73: $1157-1174$

Reed, S. C., C. C. Cleveland, and A. R. Townsend. 2007. Controls over free-living nitrogen fixation in a lowland tropical rain forest. Biotropica 39:585-592.

Reed, S. C., C. C. Cleveland, and A. R. Townsend. 2008. Tree species control rates of free-living nitrogen fixation in a tropical rain forest. Ecology 89:2924-2934.

Reed, S. C., A. R. Townsend, E. A. Davidson, and C. C. Cleveland. 2012. Stoichiometric patterns in foliar nutrient resorption across multiple scales. New Phytologist. http://dx. doi.org/10.1111/j.1469-8137.2012.04249.x

Reed, S. C., P. M. Vitousek, and C. C. Cleveland. 2011. Are patterns in nutrient limitation belowground consistent with those aboveground: results from a 4 million year chronosequence. Biogeochemistry 106:323-336.

Reich, P. B., and J. Oleksyn. 2004. Global patterns of plant leaf $\mathrm{N}$ and $\mathrm{P}$ in relation to temperature and latitude. Proceedings of the National Academy of Sciences USA 101:11001-11006.

Richardson, S. J., D. A. Peltzer, R. B. Allen, and M. S. McGlone. 2005. Resorption proficiency along a chronosequence: responses among communities and within species. Ecology 86:20-25.

Santiago, L. S., E. A. G. Schuur, and K. Silvera. 2005. Nutrient cycling and plant-soil feedbacks along a precipitation gradient in lowland Panama. Journal of Tropical Ecology 21:461-470.

Sayer, E. J., et al. 2012. Variable responses of lowland tropical forest nutrient status to fertilization and litter manipulation. Ecosystems 15:387-400.

Selmants, P. C., and S. C. Hart. 2008. Substrate age and tree islands influence carbon and nitrogen dynamics across a retrogressive semiarid chronosequence. Global Biogeochemical Cycles 22:GB1021.

Selmants, P. C., and S. C. Hart. 2010. Phosphorus and soil development: does the Walker and Syers model apply to semiarid ecosystems? Ecology 91:474-484.

Sinsabaugh, R. L. 1994. Enzymic analysis of microbial pattern and process. Biology and Fertility of Soils 17:69-74.

Sinsabaugh, R. L., R. K. Antibus, A. E. Linkins, L. Rayburn, D. Repert, and T. Weiland. 1993. Wood decomposition: nitrogen and phosphorus dynamics in relation to extracellular enzyme activity. Ecology 74:1586-1593.

Sinsabaugh, R. L., and J. J. Follstad Shah. 2012. Ecoenzymatic stoichiometry and ecological theory. Annual Review of Ecology, Evolution, and Systematics 43:313-343.

Sinsabaugh, R. L., and D. L. Moorhead. 1994. Resource allocation to extracellular enzyme production: a model for nitrogen and phosphorus control of litter decomposition. Soil Biology and Biochemistry 26:1305-1311.

Sinsabaugh, R. L., et al. 2008. Stoichiometry of soil enzyme activity at global scale. Ecology Letters 11:1252-1264.

Sjogersten, S., A. W. Cheesman, O. Lopez, and B. L. Turner. 2011. Biogeochemical processes along a nutrient gradient in a tropical ombrotrophic peatland. Biogeochemistry 104:147-163.

Stevens, P. R. 1968. A chronosequence of soils near Franz Josef glacier. Dissertation. Lincoln College, University of Canterbury, Lincoln, New Zealand.

Stewart, C. G. 2000. A test of nutrient limitation in two tropical montane forests using root ingrowth cores. Biotropica 32: 369-373.
Sullivan, B. W., and S. C. Hart. 2013. Evaluation of mechanisms controlling the priming of soil carbon along a substrate age gradient. Soil Biology and Biochemistry 58: 293-301.

Syers, J. K., A. E. Johnston, and D. Curtin. 2008. Efficiency of soil and fertilizer phosphorus use: reconciling changing concepts of soil phosphorus behaviour with agronomic information. Fertilizer and plant nutrition bulletin. Food and Agriculture Organization of the United Nations, Rome, Italy.

Tanner, E. V. J., P. M. Vitousek, and E. Cuevas. 1998. Experimental investigation of nutrient limitation of forest growth on wet tropical mountains. Ecology 79:10-22.

Thornton, P. E., J.-F. Lamarque, N. A. Rosenbloom, and N. M. Mahowald. 2007. Influence of carbon-nitrogen cycle coupling on land model response to $\mathrm{CO}_{2}$ fertilization and climate variability. Global Biogeochemical Cycles 21: GB4018.

Tilman, D., K. G. Cassman, P. A. Matson, R. Naylor, and S. Polasky. 2002. Agricultural sustainability and intensive production practices. Nature 418:671-677.

Townsend, A. R., and G. P. Asner. 2013. Multiple dimensions of resource limitation in tropical forests. Proceedings of the National Academy of Sciences USA 110:4864-4865.

Townsend, A. R., G. P. Asner, and C. C. Cleveland. 2008. The biogeochemical heterogeneity of tropical forests. Trends in Ecology and Evolution 23:424-431.

Townsend, A. R., C. C. Cleveland, G. Asner, and M. Bustamante. 2007. Controls of foliar N:P ratios in tropical rain forests. Ecology 88:107-118.

Townsend, A. R., C. C. Cleveland, B. Z. Houlton, C. B. Alden, and J. W. C. White. 2011. Multi-element regulation of the tropical forest carbon cycle. Frontiers in Ecology and the Environment 9:9-17.

Treseder, K. K., and P. M. Vitousek. 2001. Effects of soil nutrient availability on investment in acquisition of $\mathrm{N}$ and $\mathrm{P}$ in Hawaiian rain forests. Ecology 82:946-954.

van der Ploeg, R. R., W. Böhm, and M. B. Kirkham. 1999. On the origin of the theory of mineral nutrition of plants and the law of the minimum. Soil Science Society of America Journal 63:1055-1062.

Vitousek, P. M. 1982. Nutrient cycling and nutrient use efficiency. American Naturalist 119:553-572.

Vitousek, P. M. 1984. Nutrient cycling, and nutrient limitation in tropical forests. Ecology 65:285-298.

Vitousek, P. M. 1998. Foliar and litter nutrients, nutrient resorption, and decomposition in Hawaiian Metrosideros polymorpha. Ecosystems 1:401-407.

Vitousek, P. M. 2004. Nutrient cycling and limitation: Hawaii as a model system. Princeton University Press, Princeton, New Jersey, USA.

Vitousek, P. M., O. A. Chadwick, T. E. Crews, J. H. Fownes, D. M. Hendricks, and D. Herbert. 1997. Soil and ecosystem development across the Hawaiian Islands. GSA Today 7:1-8.

Vitousek, P. M., and R. W. Howarth. 1991. Nitrogen limitation on land and in the sea: how can it occur? Biogeochemistry 13: $87-115$.

Vitousek, P. M., S. Porder, B. Z. Houlton, and O. A. Chadwick. 2010. Terrestrial phosphorus limitation: mechanisms, implications, and nitrogen-phosphorus interactions. Ecological Applications 20:5-15.

Vitousek, P. M., and W. A. Reiners. 1975. Ecosystem succession and nutrient retention: a hypothesis. BioScience 25:376-381.

Walker, T. W., and J. K. Syers. 1976. The fate of phosphorus during pedogenesis. Geoderma 15:1-19.

Wright, S. J., et al. 2011. Potassium, phosphorus, or nitrogen limit root allocation, tree growth, or litter production in a lowland tropical forest. Ecology 92:1616-1625.

Yarie, J., and K. Van Cleve. 1996. Effects of carbon, fertilizer, and drought on foliar chemistry of tree species in interior Alaska. Ecological Applications 6:815-827. 